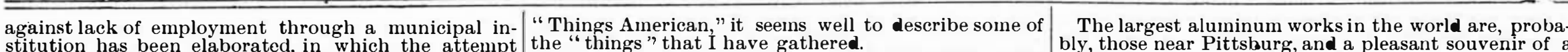
stitution has been elaborated, in which the attempt the "things" that I have gathered. has been made to meet the objections that were urged At first blush it would appear as if in so great a city visit to that city, so noted for its metallurgieal works, is against the Saint Gall experiment. The question of as New York, where everything can be had, no mat- a plaque of the coming!metal. A medallion, with the insurance against lack of employment has also received ter from where it originally cane, no special me- head of Woehler, who discovered the element, modeled
attention in other Swiss cities, notably Zurich and
mento, peculiar to the metropolis itself, was procur- in high relief, brings to inind some bitter cold days attention in other Swiss cities, notably Zurich and Lucerne, but no actual steps in this direction have as able, and yet there is nothing so artistic, so beautiful spent there several winters ago.
yet been taken. The federal government is now secuting an investigation of the whole subject of lack of tries as the Favrile glass, which Mr. Louis C. Tiffany and a specimen from its kilns-perhaps a cracker jaremployment and the means of preventing or lessening has recently invented. It is made into a variety of in the Severn or Calvert pattern, is. something that the evils resulting from it. The complete report of this original forms in vases and other objects of interest to cannot be found in every city; while the "Rebekah at investigation has not yet been made.

the Well" teapot, that originated in a pottery nearer The new combinations of color with color, of color the center of the city, is still procurable, but certainly
not in the tbric-a-brac shops, for there they prefer to over color, the deepening of tone, the subtile quality not in the dbric-a-brac shops, for there they prefer to
of the texture, the introduction of new colors, the sell, at fancy prices, English cups and saucers, decounion of metal with glass, and the wonderful ornament- rated with views of the city.

ALFRED KÖCHER AND HIS PACE MAKERS. WE publish herewith an engraving of Alfred Köcher al eff ects obtained by embedding lines and threads of
and his pace makers. For this picture, which was one colored glass into that of another while they are taken from an instantaneous photograph, we are in- in a molten state and during the operation of blowing, debted to our worthy contemporary the Illustrirte Zeitung. At the races which were arranged in the tion.
Friedenau-Wilmersorf Park, near Berlin, for the bene- As we journey from New York toward the South
tit of the sufferers from the flood Köcher succeeded in it of the sure collector of things beau-, ing the 3 minutes 32 seconds record of Joseph Fischer, from the sample rooms of the potteries of that city. which had formerly led the world. Köcher also made Köcher also made Perhaps, if he goes to the right place, he may find some city of the Union can have failed to have observed the

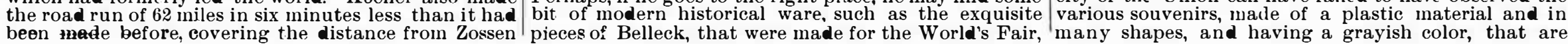

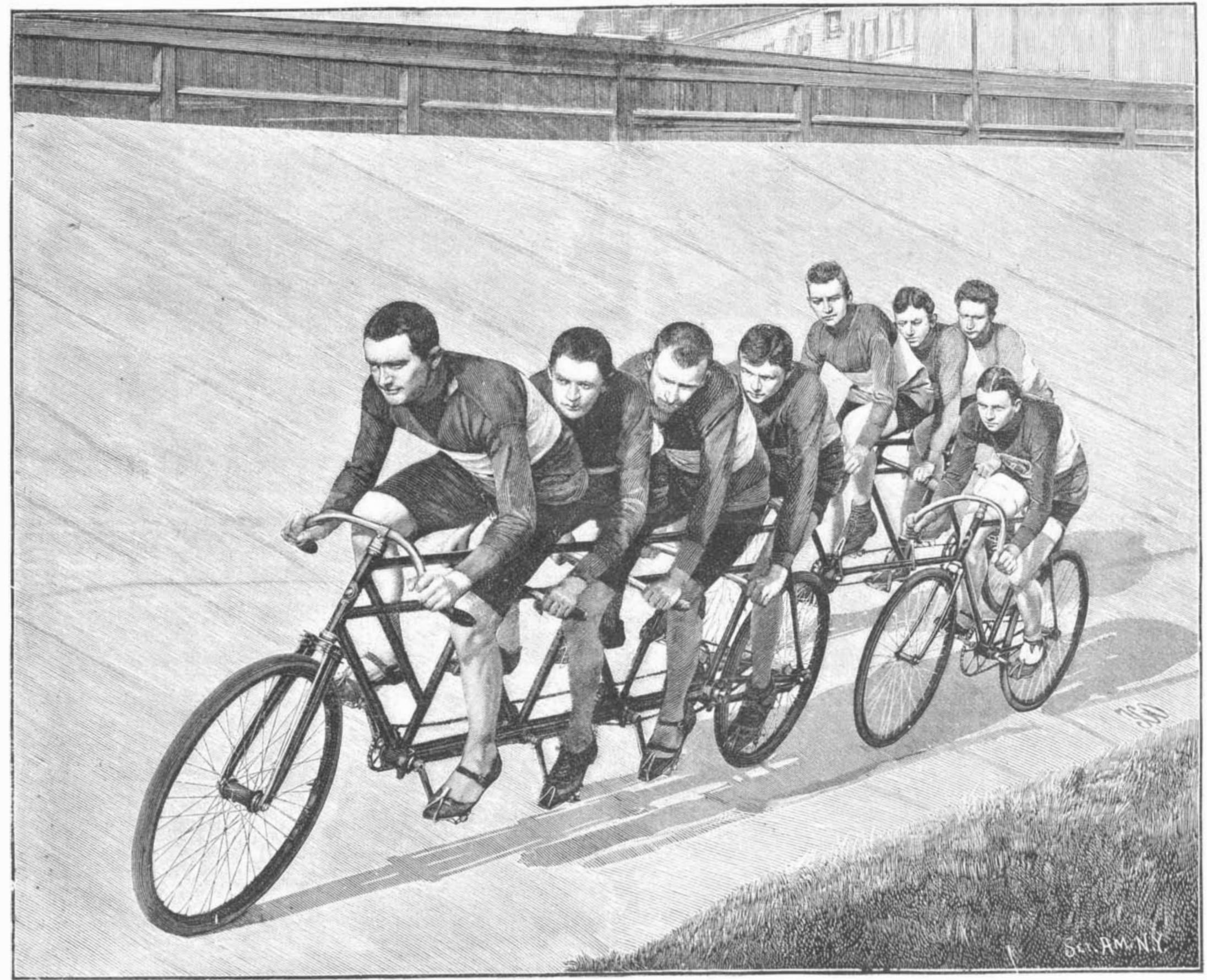

ALFRED KÖCHER AND HIS PACE MAKERS.

to Lubben and back in 2 hours, 51 minutes and 531/2 held in Chicago; or a piece of the china set, with the seconds.

\section{THINGS AMERICAN.}

By MARCís BevJaMIN, Ph.D.

IT is a curiouspeculiarity of most people that they de sire to obtain some reninders of places that they have tunately, it is apt to degenerate into vandalisin, and a piece of a curtain from the Palace of Sans Souci or a button from a Napoleonic uniform, obtained at the price of a generous douceur to the guide, is too fre-
quently the kind of souvenir that the traveler brings quently the kind of souvenir that the traveler brings
back from abroad with him. On the other hand, carved piece of bogwood from Ireland, a bit of porce lain from Sevres, a mosaic from Florence, a sash from
Rome or a piece of glass from Venice, a miniature wooden chalet from Switzerland, an agate from Oberstein, or something in iron from Berlin, are indee pleasant reminders of a visit to the old world.

who travel so much about their own country, should have so completely ignored those things that are peculiar to the many places within our own land; and yet there is scarcely an important oury own the United States Some of these deserve special mention, and as an in dames of patriotic societies, has been developed in inen contgining a vein of py rite
The rare old blue plates with which the Baltimore Whio Railway celebrated its completion in 1828 will sometimes reward the antiquarian who is willing to spend time and money to secure one of these treas. tive, that was built by Peter Cooper, sthmpy locomoIt in Washington that we find something, perhaps 
gators, so small as to be easily packed in a glove box. are everywhere sold. Fans in kright colors, like those rom the old San Marco to the modern Ponce, are jewelry, abound; while pieces of the curious coquina It is with this material that many of the newer and beautiful buildin s in St. Augustine are built.

beautiful buildings in St. Augustine are built.
It is in New Orleans that the curious carving wares
from Mexico begin to appear. Here we find the strange pottery from Guadalajara, and the wax figures that the nimble fingers of the native artists fashion with such Nor must the feather work be forgotter. for it is not
Nom Orleans to be had in the French market. If the makers of them are as old as the saleswomen, surely, in years to come, they will be rarities of the first water, commandto have been made during slave times, are not with. out interest, and may be found in shops in Canal Before leaving the Southern States, it is well to re and Confedrate bills are on sale below Mason and Dixon's line.
If we ascend the Mississippi to St. Louis, we may be fortunate in finding some authentic piece of pottery from the mounds near that city. The vicinity is rich in the remains of that prehistoric people about whom site of several mounds. Masnificent quartz crystals in Arkansas. Specimens that exceed in beauty the famous crystals from Switzerland are on sale along the principal street of the resort.
In Fexas, steer horns, fully as beautiful as those from the cattle in the vicinity of Rome, Italy, are often to
be found, and may be had for the asking. In San Antonio, with its never to be forgotten Alano, and its beautiful missions that are slowly but surely crumb-
ling into ruins, the products from over the line are sold to the curiosty hunters. Monkey jars and water bottles, feather

Turning abruptly north, we find in Denver curiosities that are of Indian origin; but to my mind, the sprouting silver buttons that resemble an open rose
are most interesting, while the large green garnets from Salida, that occur in perfect crystals, are souve-
nirs of greater local interest. Santa Fe is parexcellence the place, to purchase Indian pottery. Jake Gold's museuine specimens from most, if not all, the New Mexican Indian handicrafts. The Navaho blankets. that
are so highly prized, are to be had here, while the
more brilliant Mexican blankets, made in Santa $\mathrm{Fe}$ itmore brilliant Mexican blankets, made in Santa $F e$ it-
self, are sold for far less than elsewhere. The smaller
blankets, that cost from $\$ 3$ to $\$ 4$ in Santa Fe, readily blankets, that cost from $\$ 3$ to $\$ 4$ in Santa FE, readily
command $\$ 10$ to $\$ 15$ on the Pacific coast. Indian woven ones, are to be had, while silver ornaments, made by the Indians, will sometimes reward those who know what to ask for: and the still rarer paintings, on elk
skins, are occasionally to be had. Gems, including agates and the turquoise from the Los Cerillos mines, near by, are sold in Santa FE at reasonable prices,
while on the south side of the Plaza are silversmiths, who make the curious filigree silver work that rewhere in Northern Italy.

From Santa $F E$ westward along the lines of either The large black ollas from Santa Clara, New Mexico, make handsome ornaments, and certainly much of the ing. At Ei Paso there are Mexican curiosities to be into old Mexico by the only international horse car
line in the world he will find large stores where Mexican opals that seem almost to have borrowed their wax and feather work are lavishly displayed. Carvmay be bought at reasonable prices, and one firm offers a ninety pare catalogue with over one hundred illus-
trations for ten cents. there is an Indian reservation, and at the railway sta. tion the haughty braves who disdain to offer their ware are not loath to part with then for a few dimes. At Los appeared, although here and there old Californian bas
kets are to be had. but they command a good price. kets are to be had, but they command a good price
Orangewood comes again into notice, and slabs of it in all sizes, from a few inches up to a foot or more, are to som and fruit of the tree itself or with the more somber representations of one of the old mission churches that are in the immediate vicinity.
Naturally there are curiosity shops at the delightfu seaside resort of Coronado Beach, opposite San Diego A smali herd of ostriches are kept there on exhibition
to show the development of a new American industry. to show the development of a new American industry.
An egor, emptied of its contents, or one of the plume can readily be purchased. Polished abalone shells are
found, and the green variety is not so scarce as furthe north. 'The shells themselves are often to be picked up on the beach. I remember fans made from a littl burrowing owl being sold at Coronado. The wings are least, they are pretty souvenirs. The Mexican owls ar more expensive.

The red variety of the abalone shell that attracted my fancy was one I found in Monterey. At Santa
Cruz seaweeds pressed and grouped on cards seemed north of Santa Cruz is a group of big trees, and there I secured a square board of the mottled pine with which
when polished book covers can be made. I use it as cover for a portfolio to hold some engravings of the old missions that were purchased in San Francisco.

drive of twenty-six miles up Mount Hamilton to the perience, to say nothin of the views that are seen as the mountain is ascended. I hope Professor Holden
will pardon me if I recall as a souvenir of my visit to
low pitcher, which is of English make. The Low tiles Mount Hamilton the print of a photograph of the from Chelsea are genuine American products. 'Th' an taken at the observatory which he signed for me, witch jug from Salem, made at the Hampshire pottery ome wood from branches from trees that I cut in in-- in Keene, is also an Americanarticle, while the strange Chinese curiosities are naturally what are to be the Gayhead Pottery is. Tiles, plates and pitcher ound most abundantly in San Francisco. A dirk knife abound and are to be had with American views, such \begin{tabular}{l|l} 
in a carved bone case from Tong Yeun, in Jackson St., & abound and are to be had with American views, such \\
as the old tower in Newport or the homes of our New
\end{tabular} a reminder of a visit to Chinatown, while a knife
England poets. Hereand there are glass factories, some
of which afford things of interest. The amberine of oncealed in an imitation fan is also a trophy from the of which afford things of interest. The amberine of
Chinese quarters. In Oakland it was quite possible
reddish shaded glass, the Burmese, the Sicilian and the ntil recently to purchase jewelry, such as sleeve but- peach blow are among the varieties of interest, none of
which are now made, as far as I know, that were found the and scarf pins, inade with thin sections of gold
which are now made, as far as I know, that were found
in the show rooms of the glass makers in New Bedford ome very handsome souvenirs in California gold of held at fancy prices.

different shades for tourists. It is also possible to pro- No mention of souvenir spoons has been made, and cure the tiny gold fractional parts of a dollar which yet the time will come when the better varieties of were coined at the United States branch mint in San these will be highly prized by those who were wise
Francisco some years ago. They are no longer made, enough to collect them when the craze was on. There and certain dates command a premium among numisThere is a Chinese quarter in Portland, Oregon, and he so desires. A pack of Chinese playing cards that tions of the Union.
ne vicinity of Puget sound, as in Tacoma and Seat, Indian curiosities, chiefly those made by the Ind ans from Alaska, who come down for a short while dur
ins the autumn to pick hops, are to be had. Closely oven baskets, such as those seen in Southern California, are found and also the stone carvings, representing it in nature. Who has not seen examples of natural the or the branches of a thick bush? spoons made from the horns of buffaloes or perhaps more of trees, or the branches of a thick bush ? correctly bisons : also woven mats from Alaska and person who is not up in the art will be amazed upon silver bracelets purporting to be made by the natives,
but which are said to be made in Victoria by Indians
of varieties of grafts that have been devised by nurseCorder to supply the tourists' demand.
Coning east from the Pacific coast, skins are some-
had to be acquired in order that the operation may mes procurable, but horns are more common, and fre- never prove unsuccessful. The great trouble has been heaps that are seen in the vicinity of the railway sta- that is to receive the graft and the plant whence the tions. Doubtless here and there bead work can be
had, but I failed to find any. It is at Niagara Falls

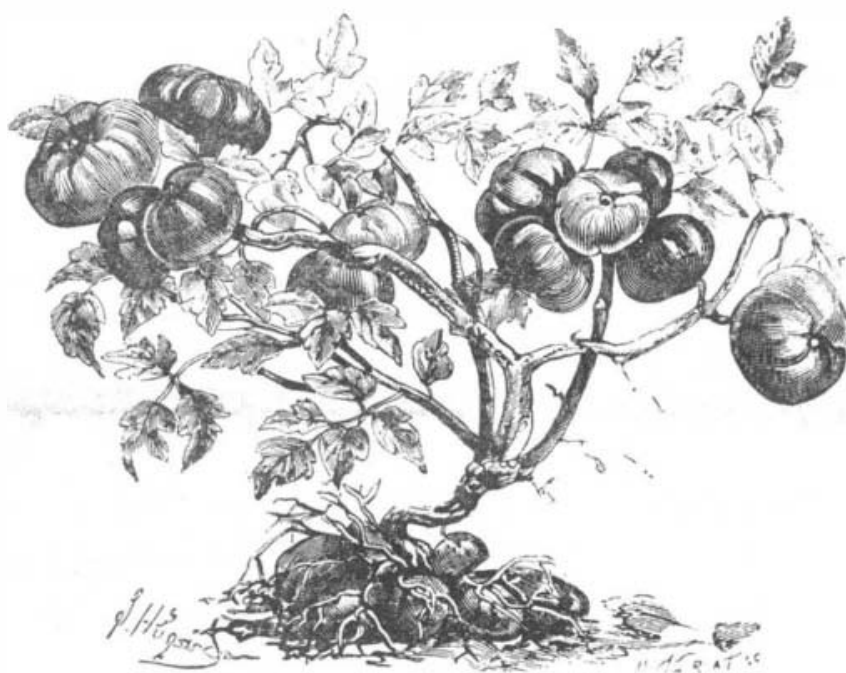

TOMATO GRAFTED UPON THE POTATO.

and similar resorts that much of the Indian beadwork shall be as similar as possible and that their multipliade into cushions and the like is to be found.
Indian pipes or calumets made from the mineral cat-
such shall occur at the same epoch. in order that
sumay unite intimately, and that the graft, linite may be bought in the Northwest, and at Sioux firmly fixed, may give the results that are expected
City are the works where the agatized wood is cut into from it. Much has been written upon this subject City are the works where the agatized wood is cut into from it. Much has been written upon this subject,
slabs, some of which are made into clock faces and the which is not yet exhausted. slabs, some of which are made into clock faces and the which is not yet exhausted. However, all are agreed
like. These are also to be had in St. Paul. What to look for in Chicago is indeed a question. Relics of the that the point, associated shall belong to the same great fire are presumably no longer obtainable, but I family, if not to the same genus, in order that the graft
well recollect a little bell that purported to be made may take. If there are any excepi ions to this rule. from the molten metal of the big bells of the City Hall they must be very rare. It is curious to find, even,
that were common in 1873 . Probably souvenirs of the that some species placed very near each other in classiWorld's Fair held in 1893 would be more easily obtain.
- fication absolutely refuse to unite, and that the adheable. There were many such, and perhaps something bion of others proves of short duration. We may here were torn down. Exquisite bronzes reproducing in miniature the animals that were conspicuous on the grounds, notably the grizzly bear by Proctor, were
made, but they were very expensive. The Columbian half dollars or the Isabella quarters are not bad remind ers of the Exposition, and even the tickets of admission, well worth preserving. products are everywhere conceded to be exquisite works of art. The "aerial blue" coloring is one of the latest of its many styles and is the most admired by
some. The rare Matt Morgan, Kezonta, and Avo wares were also made in Cincinuati, but the potterie where these were produced have long since ceased to
exist. Curious pieces of pottery are also to be had in exist. Curious pieces of pottery are also to be had in
East Liverpool and Steubenville, Ohio. The usual run of curiosities are to be had at Niagara; besides the purchased. but inost of the articles on sale are from sewhere, especially the agates. A fossil lingula from the Niagara limestone, found along the line of th
river, caine to me from the hands of Joseph LeConte one; iof the greatest of American geologists, is a souveni
of a visit to the falls with a party of geologists. As we of a visit to the falls with a party of geolozists. As we
come nearer home I am reninded of a day spent in Utica searching for the American imitations of the old
Flemish blue stoneware. Unfortunately, the maker persists in adorning his wares with Germian legends procured. In Albany, an enterprising jeweler had
made in Austria some articles of the brilliant decorated Hungarian glass, which, even though made in Europe have desigus that recall local events of the times of the In New England souvenirs run largely to pottery.
Rare bits of the Chelsea falence are still occasionally
of the results, obtained a crop of tomatoes upon stems
of thet-sweet. Mr. C. Baltet, and experiuenter of art of grafting: in the grafting of different species is still wanting. No explanation, either, has been given as to why certain genera can be grafted upon others without the recipro-
cal being possible. For example, the apple does not succeed upon the pear; while we have seen the latter living for some years upon the former. The pear adopts these plants do not render the same service to their ally. 'The service. medlar, quince and quickbeam, which are so unlike each other and the white thorn,
all sympathize with the latter. The peach and apricot graft upon each other with difficulty, while both succeed upon the almond and plum. All the clerries graft
upon the mahaleb, but the latter grafts upon no The number of such examples that have been revealed know a priori, might be still further increased. now a priori, might be still further increased.
Grafting has rendered and is still rendering great service in the multiplication of sarmentous plants such as clematises, or, again, of peonies, and even of certain by slips; and it is then upon roots that the grafting is practiced, the subjects selected being vigorous species
or varieties always belonging to the same genus. It is also possible to graft annual plants when these
have stalks or branches that are sufficiently fleshy, and a striking example of this is shown in the aeconpanying a striking example of this is shown in the aecompanying
engraving. It cannot be said, however, that this pro-
cess has entered into practice, and up to the present it has been merely a matter of curiosity. Carrière, who was a practical man and an indefatigable investigator,
tried the most diverse kinds of grafting, and among 